\title{
A Blot on the Landscape? Civic Memory and Municipal Public Parks in Early Twentieth Century Manchester
}

\author{
Dr Carole O'Reilly
}

Senior Lecturer in Media \& Cultural Studies

School of Arts and Media

University of Salford

MediaCity UK

Salford M50 2HE

Tel: 01612956054

\section{Email: c.oreilly@salford.ac.uk}

\begin{abstract}
This paper examines the decision to locate the façade of Manchester's old Town Hall in a public park (Heaton Park) in 1912. It argues that, in so doing, the city's Parks and Cemeteries committee was attempting to refine the didactic space of the park as a site of civic memory. The early Victorian urban parks had sought to educate their visitors through their museums, art galleries and exhibition spaces, glasshouses and carefullyplanned and planted walkways. The insertion into this environment of part of a former civic building was intended to remind the visitors of their civic history and to warn surrounding districts of the expansionist tendencies of the city of Manchester. The failure to identify the façade or to connect it to its surroundings meant that its meaning was ultimately lost to many parks visitors and it remained in place as a civic folly. Public parks presented the municipal authorities with an opportunity to highlight the provision of recreation and leisure facilities, but also an occasion to re-invent the municipal tradition. However, as this paper shows, such gestures were often futile in the complex and contested space of the public park.
\end{abstract}

\section{Keywords}


Public parks; civic memory; urban architecture; Manchester City Council; Heaton Park; urban heritage; active citizens

\section{Introduction: Landscape, Conservation and the Invention of Tradition}

Landscape, as Schama suggested, carries the 'freight of history' (Schama 1996, p. 5).

Nowhere is this more evident than in the space of the public park. Such landscapes are a product of our culture and our history but often reuse and redefine that history in new ways (ibid.). In February 1912, the Art Sectional committee of the Education committee of Manchester City Council decided to preserve the colonnaded façade of the old King Street Town Hall (1822-5), which had become a Reference Library after the construction of the new Town Hall in Albert Square in 1877. In keeping with the architectural fashion of the time, the new Town Hall was designed by Alfred Waterhouse in the Gothic Revival style. The old Town Hall was a classical building whose symmetrical proportions had fallen out of favour (Figure 1).

It was designed by Francis Goodwin (whose patron was the influential Sir John Soane) and based on the Erechtheum in Athens. The façade was composed of a colonnade of four ionic columns, a covered loggia, the colonnade doorway and the entire portico of the building, including the statuary. In common with many town halls of this period, it was not freestanding and was designed to fit in with the existing streetscape (Cunningham 1981). The classical frontage echoed that of Salford Town Hall (1825-7) and other comparable examples from this period. Goodwin designed a similar town hall for nearby Macclesfield in 1823 (Cunningham 1981). The use of a pillared front emphasised the façade of the building and marked a new stage of development of town hall architecture away from the rather plain buildings of the eighteenth century and before the flourishing of the Gothic Revival in the later nineteenth century (Cunningham 1981). These buildings were a new type of municipal architecture based on designs for mansion houses and royal exchanges (Cunningham 1981). The demolition of the King Street building in 1912 resulted in the idea of preserving the façade and erecting it in one of Manchester's municipal public parks. 
This paper examines the influences on the decision to preserve the facade utilising the concepts of civic pride, the invention of tradition and the social significance of the municipal past. It argues that preserving the façade was an extension of the Victorian impetus to revere the past while transforming the present via the use of historical artefacts. However, the early twentieth century public park extended this by being less directly didactic and leaving the object to speak for itself. The choice of a public park for the facade demonstrates the increasing social and historical significance of these landscapes as sites of multiple meaning that extend considerably beyond their recreational and leisure uses. The park thus became a symbol of the civic history of Manchester and the continuation of municipal attempts to invent a civic tradition for the city.

Manchester was one of the early pioneers of public parks, with the first three opening in 1846 - Philips Park, Queen's Park and Peel Park. The acquisition of the 650acre Heaton Park to the north of the city in 1901 was the culmination of a period of steady accumulation of parkland by the City Council. It also represented the beginnings of the age of Edwardian park-making in the city which deviated from its Victorian forebears in providing public spaces not just for recreation but for a diversity of activities, both planned and unplanned. The incorporation of Heaton Park into the city represented the territorial expansionism begun in 1885 and cemented Manchester's reputation as a major urban centre. Municipal public parks were also an important component of civic pride and reflected an ongoing rivalry between rapidly developing cities such as Manchester, Leeds and Liverpool.

With one eye on the future, however, the city also began to acknowledge the importance of its past. Kidd has pointed out the penchant for the pre-industrial past in Manchester, as epitomised by the building of a model of the sixteenth century city for the 1887 Royal Jubilee exhibition (1997, p. 19). In the Edwardian period, this re-assessment of the civic past continued with the decision to preserve the old Town Hall façade. Lowenthal has commented that the display of artefacts enhances their appeal and the decision to separate the façade from the rest of the building illuminates the attitudes of the City Council not only to its own civic history but also to the usage of open space for the purposes of displaying that history (1985, p. 271). Hobsbawm has shown how local 
authorities re-presented aspects of the civic past to the citizens to emphasise their influence and to re-create a new version of municipal history with themselves at the centre (1983, pp.1-15). This suggestion will be used to examine the conservation of the Town Hall façade and its re-presentation to the citizens in a municipal park.

Assumptions about the didactic nature of art were made during the Victorian period, hence the attempts to blend recreation with learning in many public parks of this era. An appreciation of art was the responsibility of the educated middle classes to pass onto the working classes by encouraging them to follow their example and visit museums and galleries and, where these could be incorporated into public parks such as Heaton Park, Peel Park and Queen's Park, this was regarded as beneficial for all. The Victorian public park was also envisaged as providing an open space where all social classes could mingle and a spirit of self-reliance and social responsibility could be shared. This proved a false hope as many of the wealthier members of the middle classes had already abandoned the cities for the suburbs as Offer has pointed out (1981, p. 125). The early twentieth century public park, on the other hand, encouraged visitors to be self-improvers and displaying historical artefacts in the park turned the visitor's attention beyond the immediate landscape to that of the nearby city.

\section{Manchester City Council and Civic Pride}

The initial impetus to preserve the old Town Hall façade came from local architect Edgar Wood (1860-1935), who was president of the Manchester Society of Architects. Wood was an architect in the Arts and Crafts style and had a particular regard for Classical buildings (Archer 1963, p. 156). The response of Manchester City Council's Parks and Cemeteries committee to Wood's request was initially negative but they did agree to receive a deputation which included Wood, T. C. Horsfall from the Royal Manchester Institution and Councillor Sir Alexander Porter of the Education committee (MA, GB127.M9/68/31, p. 122). Horsfall co-founded the Citizens' Association for the Improvement of the Unwholesome Dwellings and Surroundings of the People in 1902 and was a firm believer in the didactic power of art (Harrison 1985, p. 122). He was the motivating force in the establishment of the Manchester Art Museum in the heart of a working class district, Ancoats. He observed that the inhabitants of Manchester had 
'nothing offered to them by the community that can make them respect their city and feel glad to be alive' (1905, p. 22). Labour Councillor Thomas Marr was also involved in the campaign, having moved from Edinburgh to Manchester in 1902 and elected to the City Council in 1905. He was active in the Art Museum with Horsfall and argued that the principle role of the municipality was to ensure the development of a healthy citizenry (ibid., p. 124).

The deputation presented their plans for the preservation of the façade to a meeting of the Parks and Cemeteries committee in February 1912, along with a supportive letter signed by 156 people who included the Bishop of Salford, Louis Casartelli and the artist Lawrence Alma-Tadema. It was argued that the façade was a 'dignified and monumental refinement', 'a noble inheritance' and 'part of the history of the city' (MA, GB127.M9/68/31, p. 125), thus establishing a relationship between civic pride and architectural history. Wyke has pointed out that the involvement of socially prominent individuals in campaigns such as this and others (the campaign to build the Albert Memorial in Manchester, for instance) provided some legitimation for the enterprise (2007, p. 112). Many of those involved in the campaign were not from the city of Manchester itself nor were they all City Council members. Architects and antiquarians alike, they were primarily interested in the façade as a part of the architectural history of the city as well as appreciating its civic significance.

After receiving the deputation, the Parks and Cemeteries committee resolved to proceed with the preservation of the façade, provided that half of the cost (£500) could be raised by public subscription in order to demonstrate the support of the wider public for the scheme. Wood and his colleagues successfully raised the money and the Parks and Cemeteries committee began to consider locations for the façade in a city park.

The reactions of the members of the full City Council to the plan to re-erect the façade in one of the city's parks were mixed. The first suitable park identified was the recently opened Platt Fields Park in Rusholme (90 acres, purchased in 1907). Many councillors thought the façade was too tall to be near Platt Hall (Manchester City News, 4 May 1912), signifying that the monumental aesthetics of the colonnade were problematic in such a space. Public opinion in the Rusholme area suggested that there was little support for the presence of the facade in Platt Fields Park, with the Manchester Evening 
News reporting that local people felt that it would be a 'blot on the landscape' of the park (Manchester Evening News, 17 May 1912). This was reflected in a decision by the full City Council on 1 May 1912 to refer the choice of site at Platt Fields Park back to the Parks and Cemeteries committee (MA, GB127.M9/68/1/31, p. 183).

There were also divisions within the committee on the subject. Councillor Day (Independent, Gorton South) said he would be glad to have it if the committee would provide a park in the working-class district of Gorton to go with it (Manchester City News, 8 June, 1912). Gorton had been asking for a public park since the 1840s and had yet to get one. Councillor Harrop (Liberal, chair of the Parks and Cemeteries committee) explained the reasons for the preservation - pressure from an important deputation of businessmen and a subscriber list of $£ 500$ (ibid.). Councillor Fox (Labour) rejected the plan and called for the façade to be 'tipped into some backyard' (Manchester Courier, 7 June, 1912).

On the preservationist side, Councillor Clyne (Independent) argued that the façade would be 'full of pleasant memories and a pride to the city' (Manchester Guardian, 6 June, 1912). A letter writer to the Manchester City News described the façade as 'a folly' and indicative of the 'wasteful extravagance' of the Council, a common accusation levelled at any municipal spending (Manchester City News, 18 May, 1912). Another correspondent, Conservative Councillor F. J. Robertshaw called the façade a 'foolish freak', accused the Parks and Cemeteries committee of getting carried away by a minority and suggested burying it in the boating lake at Heaton Park. It is worth noting that both support for and opposition to the façade was not aligned to political party affiliation - its detractors came from Labour, Liberal, Conservative and independent members. There is, however, evidence that some councillors supported the erection of the façade in public parks near the wards they represented. Thus, Councillors Cook (Liberal) of Didsbury and Bowie (Liberal) of East Moss Side proposed Platt Fields Park as the location while Councillor Bennett (Liberal) of Blackley and Moston suggested it as an entrance to Boggart Hole Clough, a park in Blackley, north Manchester (Manchester City News, 8 June, 1912).

The conservative Manchester Courier newspaper referred to the façade as possessing 'dignity and nobility' and went on to challenge the philistinism of local 
councillors whom, it alleged, lacked any appreciation of art and beauty. It elaborated on this by suggesting that any attempts to improve the urban landscape of Manchester were met by the indifference of the City Council (Manchester Courier, 7 June, 1912). In fact, this was an unjustified criticism. The City had been investing for many years in the purchase and laying out of public parks - the number of acres devoted to parks in the city tripled in the ten years between 1902 and 1912, from 411 acres to 1305 acres.

However, Manchester City Council had an inconsistent approach to conservation at this time. In 1896, the City Council purchased Clayton Hall, the home of Humphrey Chetham along with eight acres of land. Chetham was a seventeenth century merchant who had established Chetham's Hospital and Chetham's Library in Manchester. Although the explicit reasons for the purchase were unclear at the time, it is likely that it was for the associations with Chetham, rather than any expansionist tendencies in the City Council as the amount of land involved was small. In April of that year, they contemplated demolishing the house but this was not proceeded with (Manchester City News, 18 April, 1896). Hendham Hall in Queen's Park (acquired in 1846) was demolished in 1880 to make way for a new building. St Peter's Church designed by James Wyatt with a tower by Francis Goodwin was demolished in 1907 (Hartwell and Wyke 2007, p.10).

The liberal Manchester Guardian, arguably the city's most influential newspaper, supported the proposal to save the facade commenting that it was especially suitable for public erection due to its being one of the most creditable examples of local classical architecture as well as a symbol of civic pride (Manchester Guardian, 16 February, 1912). Despite the decline in interest in the Gothic Revival style at this time, feelings were still mixed about the historical significance and relevance of classical styles of architecture. A rediscovery of the English Baroque tradition of Wren and Vanbrugh during the early twentieth century did not result in a widespread return to classical style (Service 1977, p. 144). However, there remained a strong sense of affinity with the history and culture of ancient Greece, as Turner has demonstrated (1981, p. 11). This included Greece's association with the birth of democracy, an ideal still cherished in the early years of the twentieth century (ibid., p. 11). The façade's association with the old Town Hall had a similar resonance. 
As Wyke has remarked, parks were often controversial locations for statues of local figures (2006, p. 87). This also explains the failure to agree on a suitable location for the façade. In part, this was a response to the ongoing debate about the functions of open space in cities, which had been underway since the mid-Victorian period. The Victorian municipal park was often a highly regulated and formally planted space whose main aim was to function as a peaceful haven, which would have a civilising effect on its visitors (Billinge 1996, pp. 443-459, Conway 1991, Bailey 1978). This 'rational recreation', therefore, grew out of an attempt to provide role models for selfimprovement among the working classes and to encourage the adoption of the values of a new urban middle-class, which considered itself both culturally and morally superior (Stobart 2003, p. 168).

This classical 'social control' model of the public park has been challenged by Stedman Jones (1983) who argued that such 'top-down' ideas about public leisure and the role of parks have been too narrowly focused. He suggested that social control is impossible to measure and is therefore lacking value. Attempts to use public parks as agents of social control were meaningless as existing leisure pursuits commonly associated with the working classes such as drinking and gambling continued alongside and, in many cases, within the parks themselves. A public park was also recognised as an educational environment in itself with the emphasis on the direction and guidance of 'the people'. Such parks were originally envisaged as spaces where all social classes could mingle but this aspiration was not attained as most of the wealthy had already left the cities in favour of the suburbs (Conway 1991, p. 3).

By the late Victorian period, most municipal authorities had accepted that it was their responsibility to provide amenities and services for the citizens. In the case of Manchester, this was already underway with successful gas, electricity, tramway and water supply projects established (Moore 2006, p. 124). The increasing municipal confidence that resulted from these enterprises aided the development of the Edwardian park - an often less formal space than its more formally planned Victorian counterpart. Conway has pointed out the tensions that resulted from designing and laying out a landscape and the provision of amenities for visitors (1991, p. 83). A park like Heaton Park had a rich history due to its previous existence as an aristocratic estate, which then 
became a public space. The opportunity afforded by a park of this type and size was quite new in Manchester, whose existing parks were smaller and easier to manage. The advantage of Heaton Park was to provide a blank canvas on which a new civic and public history could be inscribed.

Hobsbawm has written of the importance of the 'invention of tradition' - a tendency of municipal authorities to create a 'factitious' version of the past and their own place in it $(1983$, p. 9). This term was used to refer to a process of formalisation and ritualisation, which was designed to establish or legitimise authority. The aim was to assist the audience to understand the significance of the event and the role of the civic elite within it. This is also a useful term to assist in understanding the factors behind the decision to move the colonnade to Heaton Park. It has been suggested that continuity with the past was crucial in the invention of tradition as it allowed a contrast to be developed between a dynamic modern world and an unchanging and constant past (ibid., pp. 1-2). Displaying the façade in a popular venue such as a park emphasised its importance, much as the display of an artefact in a museum or art gallery. In treating a public park as a similar site of cultural value, the municipal authorities were not only legitimising their own history but also reminding the citizens of the historical value of civic memory itself.

\section{Heritage, Education and the Active Citizen}

Civic pride exerted a powerful influence at this time and was regularly used to support the development of such cultural capital as art galleries, libraries and museums in cities (Stobart 2004). Pride in any city was linked to a strong tradition of civic competitiveness among many British cities, often fuelled by the rhetoric of the local newspapers. Civic amenities were not merely about providing improving amenities for citizens but they symbolised the success of the city itself. The creation and landscaping of open spaces, civic buildings and commercial streets had the capacity to represent the city and to connect its citizens to it. In this way, cities were often defined by an absence, by what they lacked as much as by what they contained. The campaign for a new public square in Sheffield in 1911 was dominated by references to neighbouring cities (Leeds, Liverpool and Manchester), all of which had what Sheffield did not - a major public square in their 
heart (White 2006). The absence of such elements interfered with the citizen's ability to form strong psychological connections to their city and disrupted the civic memory.

Parks had, therefore, long been identified as significant elements of civic pride, engendering rivalry between neighbouring cities. The Victorian public park had sought to educate its visitors by including art galleries, museums and planting guides to enlighten and stimulate. These spaces also included historical artefacts such as war memorials, war trophies like Crimean cannons and statues of locally and nationally significant figures such as Robert Peel and Joseph Brotherton in Peel Park, Salford. Wyke has pointed out how the symbolic and historical meanings of these objects deteriorated over time, along with their physical condition (2006, p. 95). In 1919 a statue of Abraham Lincoln was placed in Platt Fields Park in Manchester demonstrating that the city was not adverse to the location of such objects in its open spaces. The statue was removed to a city centre square in 1986 (ibid., pp. 90-1).

The purpose of the early twentieth century public park was to be a less regulated and more varied space where visitors could stroll or play tennis but could also be reminded of the importance of their own civic history and their role in preserving it. Visitors to Victorian parks were monitored by the park-keepers and expected to obey the rules prominently displayed. Early twentieth century parks users were envisaged as more socially responsible and self-aware citizens who were collectively responsible for the maintenance of the appropriate social standards and behaviours (O'Reilly 2009). This was reinforced by the decision to relocate the façade to a public park instead of either demolishing it or even incorporating it into a new building. The façade was not just there to be admired but to be offered protection for the benefit of future generations.

The symbolic nature of the decision to preserve the facade cannot be underestimated. Stobart has argued that town halls have functioned as important emblems of municipal authority (2003, p. 168). The town hall signified the status of the town and was the epicentre as a 'place of assembly' (Cunningham 1981, p. 64). While size and splendour were important, so too was style. Cunningham (1981) suggested that since 'their symbolic language needed to be readily understood, they tend to use an established architectural vocabulary' (Cunningham 1981, p. 119). Since the town hall did not have a tower as such, it was the classical façade that was identified as worthy of preservation 
and of further usefulness. The town halls of the late eighteenth and early nineteenth centuries tended to copy the styles of existing classical country houses. Later town halls began to utilise the Gothic style, in part to accommodate the variety of office spaces required (Cunningham 1981).

The preservation of the classical façade of a former town hall in this manner served as a reminder of the civic past of Manchester. As Morgan has commented 'the power of naming, placing or destroying is crucial to the shaping of the memories from which identities, stories and histories may be constructed' (Morgan 1998, pp. 103-4). It re-emphasised the public ownership of the park and the civic vision of those instrumental in the purchase and sought to focus the minds of the citizens on their own civic history. The façade was to act as a potent symbol of the history of the city and those who served it and created it. Relocating it to the park moved a part of Manchester's civic history into what had until recently been the privately owned space of one aristocratic family, the Egertons, Earls of Wilton. The removal of the Town Hall façade to Heaton Park was both an attempt to preserve an element of Manchester's civic and architectural history and to connect the park visitors directly to their own history and that of their city. A newer form of park history was emerging that could co-exist with the park's original history but that had a different meaning for its visitors and served not only to legitimate the municipal owners but all of the people of the city (Lowenthal 1985, p. 44).

A desire to preserve the past (even the relatively recent past represented by the façade) had begun to gather pace during the Victorian era and this continued into the Edwardian period. During the same time as the debate about the preservation of the old Town Hall facade, Lord Curzon purchased the fifteenth century Tattershall Castle in Lincolnshire, which was to be restored and opened to the public (Manchester Courier, 16 May, 1912). Tattershall had been under threat of purchase and export to the United States in its entirety. Curzon's purchase was followed by his championing of the Ancient Monuments Act (1913), which empowered the government to offer protection to buildings deemed to be of national significance (Lowenthal 1985). The National Trust had been established in 1893, ostensibly to preserve landscapes and open spaces. It acquired its first property, four and a half acres of cliff land, in Wales in 1895 (Waterson 1994, p. 37). 
A sense of national pride in Britain's heritage was beginning to establish itself, accompanied by the idea that the past was worth preserving for more than mere aesthetic reasons. The original Town Hall building itself was not considered for preservation in its entirety and the transfer of the façade to Heaton Park meant a loss of its original context. Nevertheless, it meant that it was preserved for the public and its consequent visibility gave any passer-by the opportunity to gain an immediate impression of the past (Lowenthal 1985, p. 245). Linking park visitors so strongly to a reminder of the city's past was an attempt to engender a feeling of being custodians of their own civic history. Glendinning has remarked that one feature of modernity is the highly charged significance acquired by historical buildings and monuments which come to represent the symbolic importance of collective identity (Glendinning 2003, p. 364). The invention of a civic tradition similarly reinforces the collective nature of city life, while the conservation of architectural features embodies a 'codified, rational, secular exercise of power and knowledge (Glendinning 2013, p. 2).

While Marne has suggested that public parks retain a 'romantic anti-urbanism' (2001, p. 424), the positioning of the façade at Heaton Park marks the intrusion of the urban into the quasi-rural space. The status of the park as a former aristocratic estate is also important - the public sphere of the Town Hall colonnade now resided in what was the privately owned space of the landed elite. As Briggs has pointed out, the municipal authorities of cities such as Manchester often themselves functioned as an 'urban aristocracy', taking the place of the departed landed families (1968, p. 94). The removal of the façade to the park marked the reclamation of the land from the aristocracy and firmly delineated the space as 'of the city'. It was the civic significance of the façade that rendered its conservation important to some members of the City Council. It was also a potent reminder of the power of the new civic elites and of their role in shaping and reshaping the urban landscape.

The façade was re-erected near the boating lake in Heaton Park at a final cost of $£ 1425$ (MA GB127.M9/68/32, p. 227 and Figure 2). There was no attempt to identify it with a label or other marker. Lowenthal has suggested that identification of an artefact lent it status but, as the façade was less than a hundred years old at the time, this was not deemed to be necessary (1985, p. 263). Konrad has warned of the difficulties of 
communicating the significance and value of an historical artefact in a public park but it is clear that the cultural and historical importance of the façade in Heaton Park was assumed (1977, p. 18). What was more controversial was the choice of location for the façade and the suitability of the chosen landscape. The relative size of Heaton Park compared to Manchester's other parks was considerable and permitted the City Council to display the facade prominently without it overly dominating the parkland.

The decision to locate the façade at Heaton Park may also have been influenced by the existence there of another Classical building, Heaton Hall, the country house of the Earls of Wilton, designed by James Wyatt. Wyatt exhibited his drawings for Heaton Hall at the Royal Academy in 1772 and it is considered to be his most important country house commission at this point in his career, a view echoed by architectural historians such as Pevsner and Summerson (Pevsner 1969, p. 328, Summerson 1993, p. 426). Pevsner referred to the house as the best eighteenth-century building in Manchester (1969, p. 328). The stylistic similarity of the old Town Hall façade and colonnaded garden or south front of Heaton Hall raises the question of why the decision was not made to site the façade nearer to the Hall itself. The evidence suggests no primary reason was given for its lakeside location apart from aesthetic considerations, but it may be the case that siting the façade any closer to the Hall would have detracted attention from both.

The choice of the lakeside location was also significant. References by city councillors to the use of the façade as a 'screen' at Platt Fields Park meant that it needed to be placed near a view or a backdrop which would emphasise its meaning as a Classical backdrop from which to view the rest of the park (MA GB127.M9/68/31, p. 128). The new location drew attention to its existence through its apparent incongruity. The absence of a building behind it was turned to advantage - a new opportunity to view the lake through the prism of the civic past. The view of the facade from the lake is reminiscent of the National Monument on Calton Hill, Edinburgh (Figure 3). This was also modelled on a Greek building, the Acropolis, but never completed. It was erected in 1829 to commemorate the dead of the Napoleonic wars. Another feature, of similar design, is the Queen Victoria Arch in what is now Beckett Park in Leeds. This was erected in 1858 by 
William Beckett on his Kirkstall Grange estate to commemorate the visit of the Queen to open Leeds new Town Hall.

The lake itself was one of the newest amenities at Heaton Park, completed in 1913 and the decision to erect the façade next to it presented the opportunity for a useful juxtaposition of old and new. In this context, the reference to the facade as a 'folly' by a local letter writer, gains a new resonance (Manchester City News, 18 May, 1912). In architectural terms, a folly is a purely decorative and non-functional structure, a building without an obvious purpose. Follies were also known as 'eyecatchers', used to terminate a view or punctuate a landscape (Fleming 1999, p. 187). In this sense, then, the façade functioned as a folly in its new location. Edgar Wood was given the task of designing the site for the façade, a reward for his championing of the project.

The physical size of the façade alone when pictured relative to park visitors is striking. The effect represents the power of both the city and the civic authorities. Devoid of the rest of the building, it also symbolises not just progress but also the benevolence of the city authorities. This reminds the citizens that the past and its preservation is a continuous process not one that is easily forgotten. Hobsbawm has argued that people become conscious of their own citizenship when reminded by the symbols and rituals of the urban elite (1983, p. 12). In this instance, the display of the colonnade linked the citizens of Manchester visibly to their civic past and their role as citizens. The term citizen gained increasing significance during the Edwardian period. Meacham has proposed that the Edwardian period gave rise to a new understanding of social democracy that emphasised the idea of the community and good citizenship (1994, p. 79). This vision of democracy was defined by the harmony between nature and the individual and one that worked to idealise the past and improve on the present.

Harris suggested that trade unions, co-operatives and friendly societies all provided opportunities and models of good citizenship but this could also be extended to the role of public parks at this time (1993, p. 193). A healthy citizenry contributed to a healthy nation and formed the building block of a well-ordered society. The environment of a public park could offer the opportunity to develop not just physical health but a sense of public spiritedness and civic identity. This was reinforced by the preservation of the 
colonnade and the encouragement of an appreciation for both the civic past and public architecture.

\section{Public Parks and Civic Memory}

The idea of a public park as a repository of civic heritage was not exclusive to the time period under discussion here. From the earliest beginnings of the Victorian public park in the 1840s, buildings had been used for the display of artefacts from art galleries and museums and park visitors had been encouraged to use these amenities to educate themselves about their city and its history. The didactic function of the Victorian public park was an important element of the gospel of 'rational recreation', the attempt by the middle classes to dissuade the working classes from drinking and gambling. Cunningham has pointed out that the working classes incorporated park visiting into their lives without necessarily spending less time on other pursuits (1980, p. 186).

The presence of the old Town Hall façade at Heaton Park reminded its visitors of the importance of the civic authorities in providing facilities for the citizens. The preservation of the façade continued the civic tradition of self-congratulation that was a cornerstone of much late Victorian and Edwardian civic culture. The addition of the façade to a formerly aristocratic estate such as Heaton Park was as much a symbol of the power of the new urban elite as the carefully designed landscape of the park represented the cultural and economic power of the former owners.

The Old Town Hall façade was joined in 1915 by a pontoon captured from the Turks and presented to Manchester Corporation. The pontoon was mounted on a stand, with a railing around it and displayed near the lake. A notice was fixed nearby to explain its origin (Manchester City Council Proceedings, 1915, p. 529). The pontoon no longer survives but the façade remains in place. The pontoon, unlike the façade, was less intimately connected to civic history and more a commemoration of the Dardanelles campaign. Thus, it also functioned as a reminder of the historical past, albeit one whose significance was more clearly signposted to the visitor. Such artefacts were frequently badly maintained - a Royal National Lifeboat Institute boat at Heaton Park from 1909 was by 1916 in a 'filthy condition' with a brass presentation plate that was 'quite black and unreadable' (MA GB127.M9/68/36, p. 93). 
The display of war trophies in public parks was not unusual - Corporation Park in Blackburn included cannons captured from Sevastopol during the Crimean war. Yet, the decision to place the Turkish pontoon close to the façade marks a concerted attempt to historicise this part of the park for its visitors. The success of this is debatable. There is evidence that many visitors did not recognise the façade in its new location. A letter writer to the Parks and Cemeteries committee in 1915 commented that the writer often saw 'people gazing at it and wondering what it is' and suggested the addition of a stone or brass plate to explain its origins (MA GB127.M9/68/34, p. 201). This was not undertaken. W. Vaughn Best wrote to the Manchester Guardian in 1913 to query the purpose of the façade in the park: 'one wonders what current purpose it is going to serve'. He suggested that it could function as a memorial to British architecture or a demonstration of the ineffectiveness of such an artefact when divorced from its original location. Clearly, many citizens did not yet accept the idea of art for art's sake. This demonstrates that the invention of a civic tradition was never a straightforward process and required the anchoring of an artefact firmly in municipal history. Failure to do this risked the ability of the park landscape to retell the city's history and to function fully as a symbol of the modern city of Manchester.

Manchester was not alone in attempting to preserve items from its civic past in a public park. The city of Hull also began to utilise its public parks for displaying artefacts connected to the city's history. In 1912, consideration was given to the erection of the balustrading of a staircase from the Old Town Hall at a city park as an 'ornamental feature' (HHC, TCM/2/25/6, p. 79). In the end, only part of it was placed in Pearson Park due to concerns about the overall height of the structure. The ornamental dome of the old Hull Town Hall (designed by local architect, Cuthbert Brodrick and demolished in 1911) was relocated to Pearson Park in 1912 (Figure 4). These decisions were uncontroversial in Hull, compared to Manchester. Some brief concerns about costs were raised at the Parks and Burials committee but these were over-ridden by the desire to preserve the artefacts and to put them on public display (HHC, TCM/2/34/6, p. 50).

Later that same year, Sir Albert Rollit and family presented the watchtower of the old Citadel to the city. Rollit was a former mayor of Hull and had been involved in the shipbuilding trade in the city. The watchtower was erected in East Park, Hull as part of a 
folly called the Khyber Pass, a large ornamental rockwork feature built by EA Peak between 1885-1888 (HHC, TCM/2/25/6, p. 78). The watchtower was eventually relocated near to its original site at Hull's Victoria Dock in 1991.

Such a prominent and permanent reminder of the city's past in a popular open space reinforced ideas about civic pride, civic memory and the municipal project to create a modern and progressive city to rival others. The preservation of the Manchester Town Hall façade demonstrates that, even by 1912, the Victorian imperative to educate the citizens in order to encourage self-improvement and social order was still influential. Though the impetus for the preservation came from bodies outside the City Council such as the Royal Manchester Institution and the Manchester Society of Architects, the agreement of the civic authorities and the subsequent debates about the location of the façade demonstrates that both its aesthetic qualities and symbolic importance were recognised.

The early twentieth century public park, however, had begun to develop its own distinctive features. Large parks like Heaton Park had the capacity to accommodate historical artefacts but were also closely linked to a display of civic power on the part of their new owners. The removal of the facade of the Manchester's old Town Hall to a park on its north-western border sent a clear signal to the neighbouring boroughs of Prestwich, Middleton and Whitefield about the expansionist intentions of the municipality. Manchester had made previous and unsuccessful attempts to incorporate these boroughs into the city and the purchase of Heaton Park had increased the threat to their future status even further.

Far from being a blot on the landscape, the façade represented the preservation and promotion of the civic gospel of Manchester and its traditions. Landscapes can be 'self-consciously designed to express the virtues of a particular political or social community' (Schama 1996, p. 15). Heaton Park was not designed by the civic authorities but by its former aristocratic owners as a reflection of their social and economic power. The civic history of the city of Manchester was then superimposed on this land to extend its resonance and to begin to align its aristocratic past with its municipal past. 


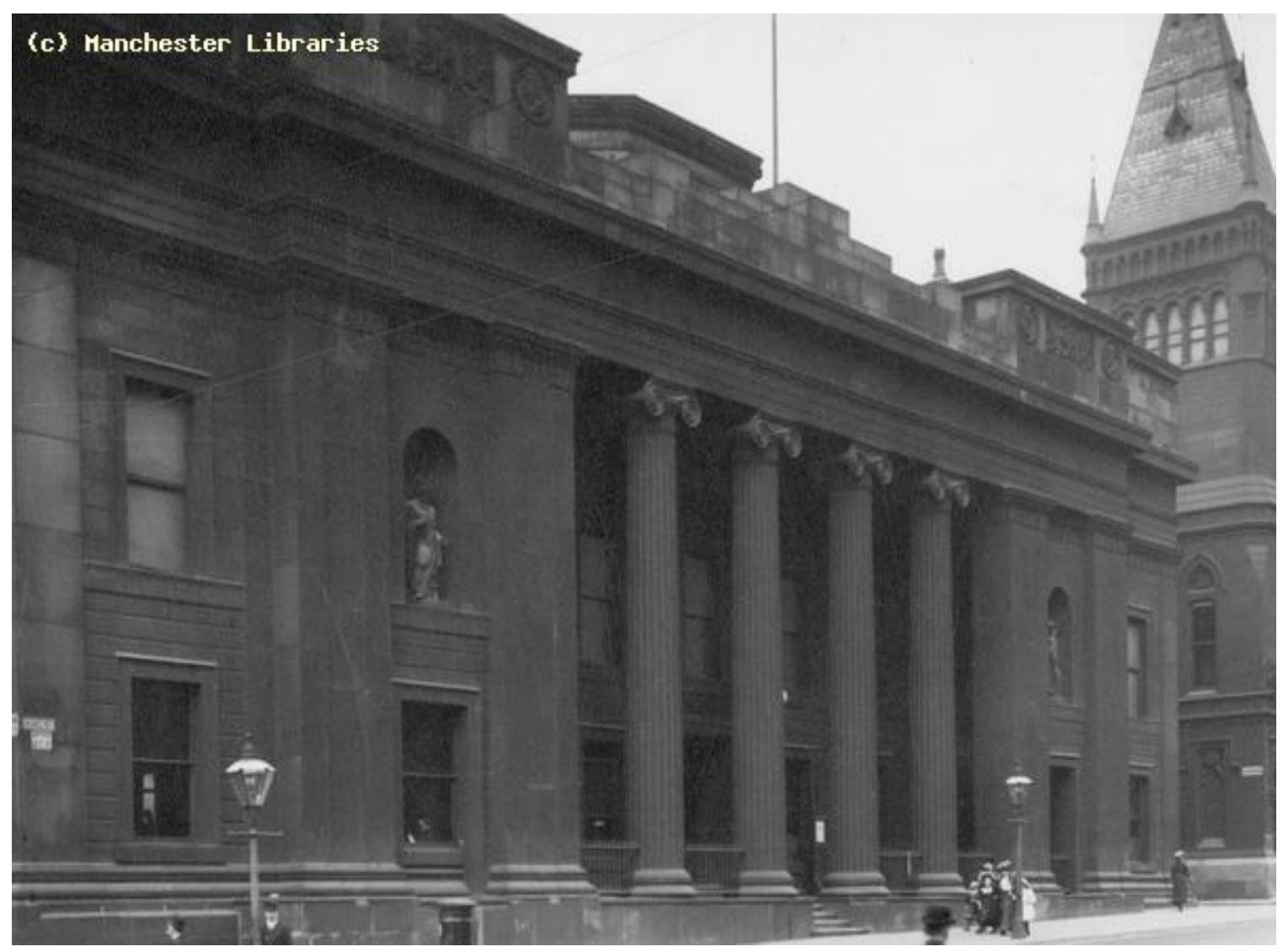

Figure 1 - The Old Town Hall, King Street, Manchester with the colonnade in situ (Manchester Central Library, Local Image collection) 


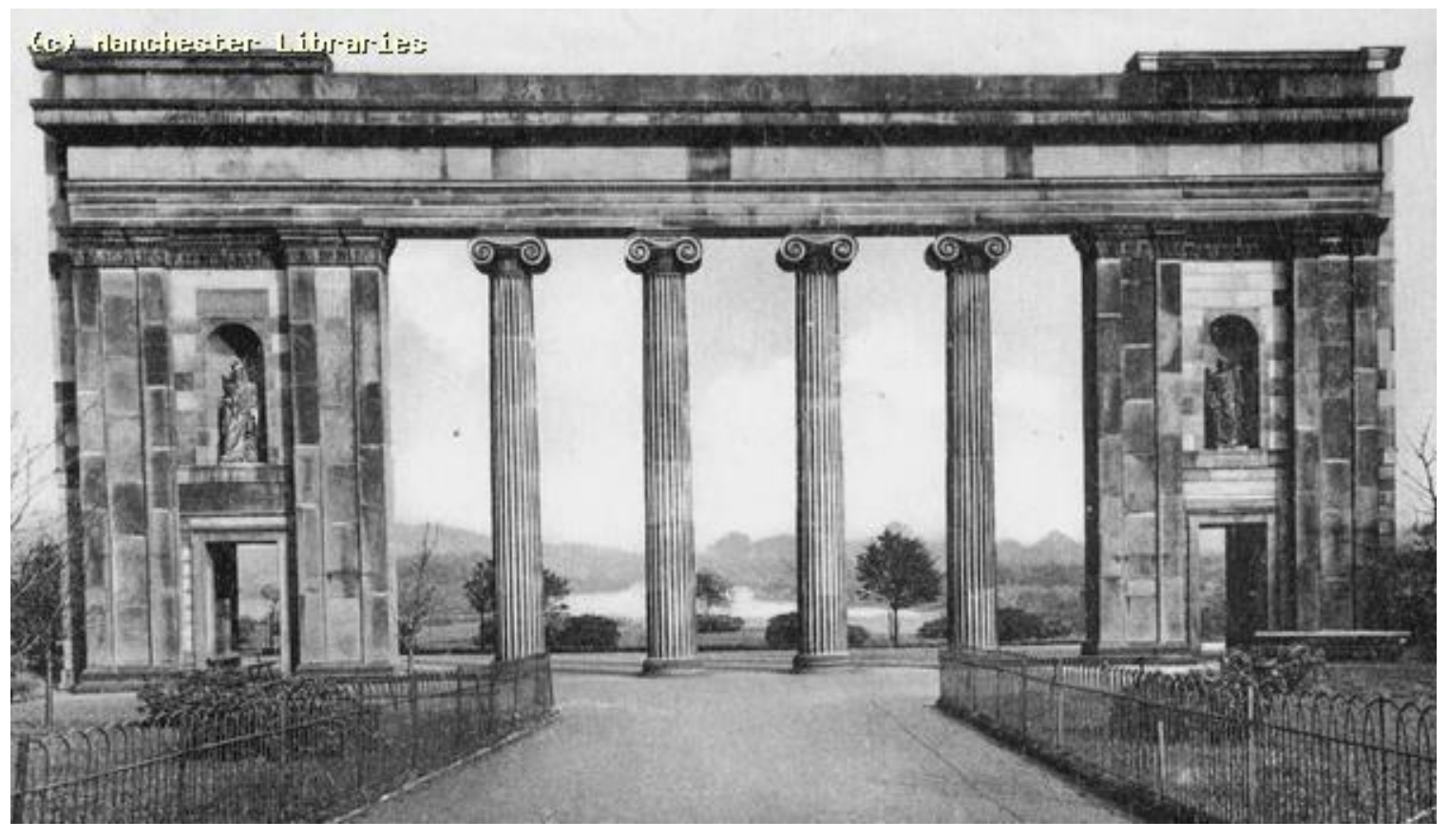

Figure 2 - The façade at Heaton Park (Manchester Central Library, Local Image collection) 


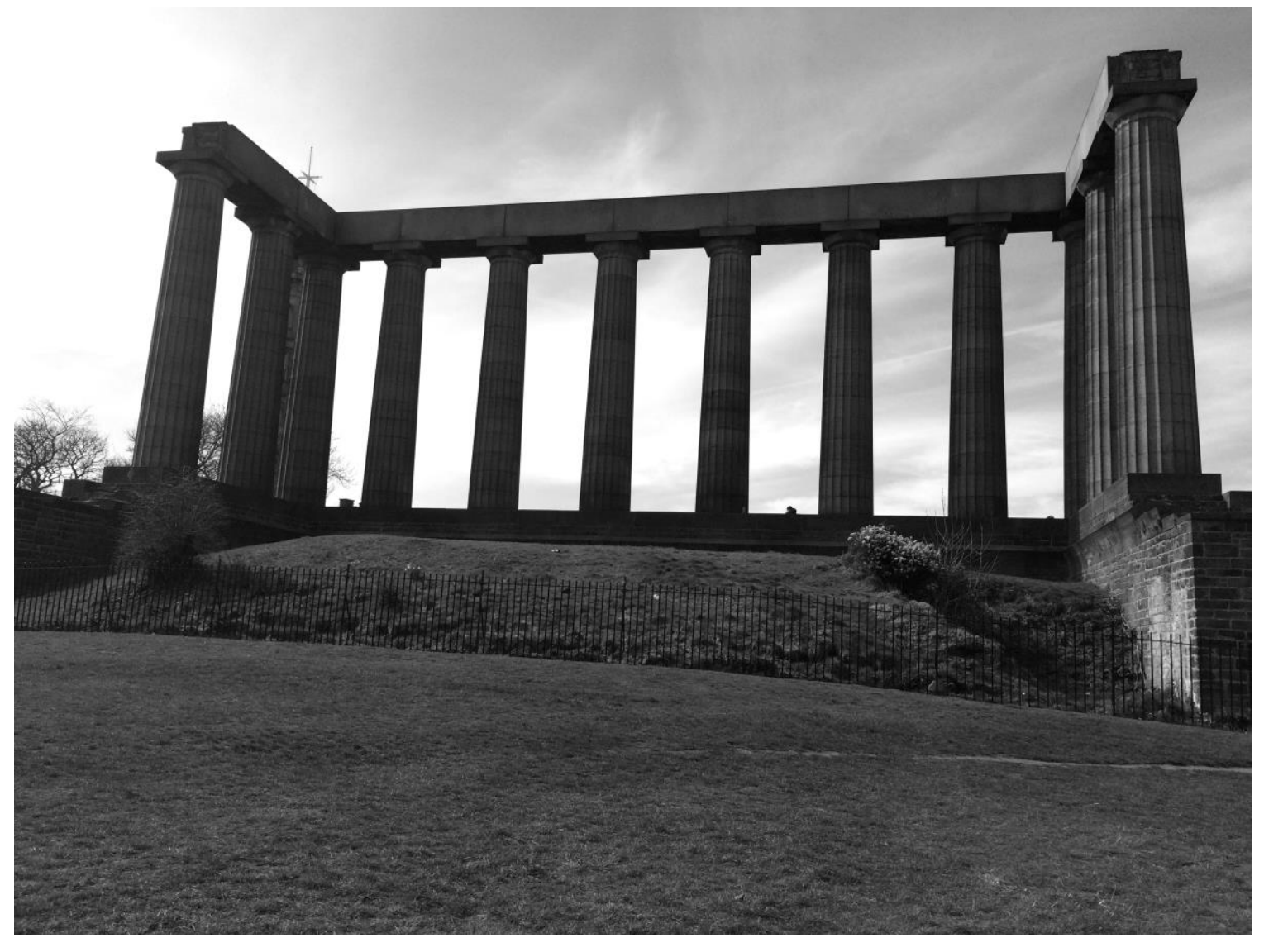

Figure 3 - The National Monument, Calton Hill, Edinburgh (author photo) 


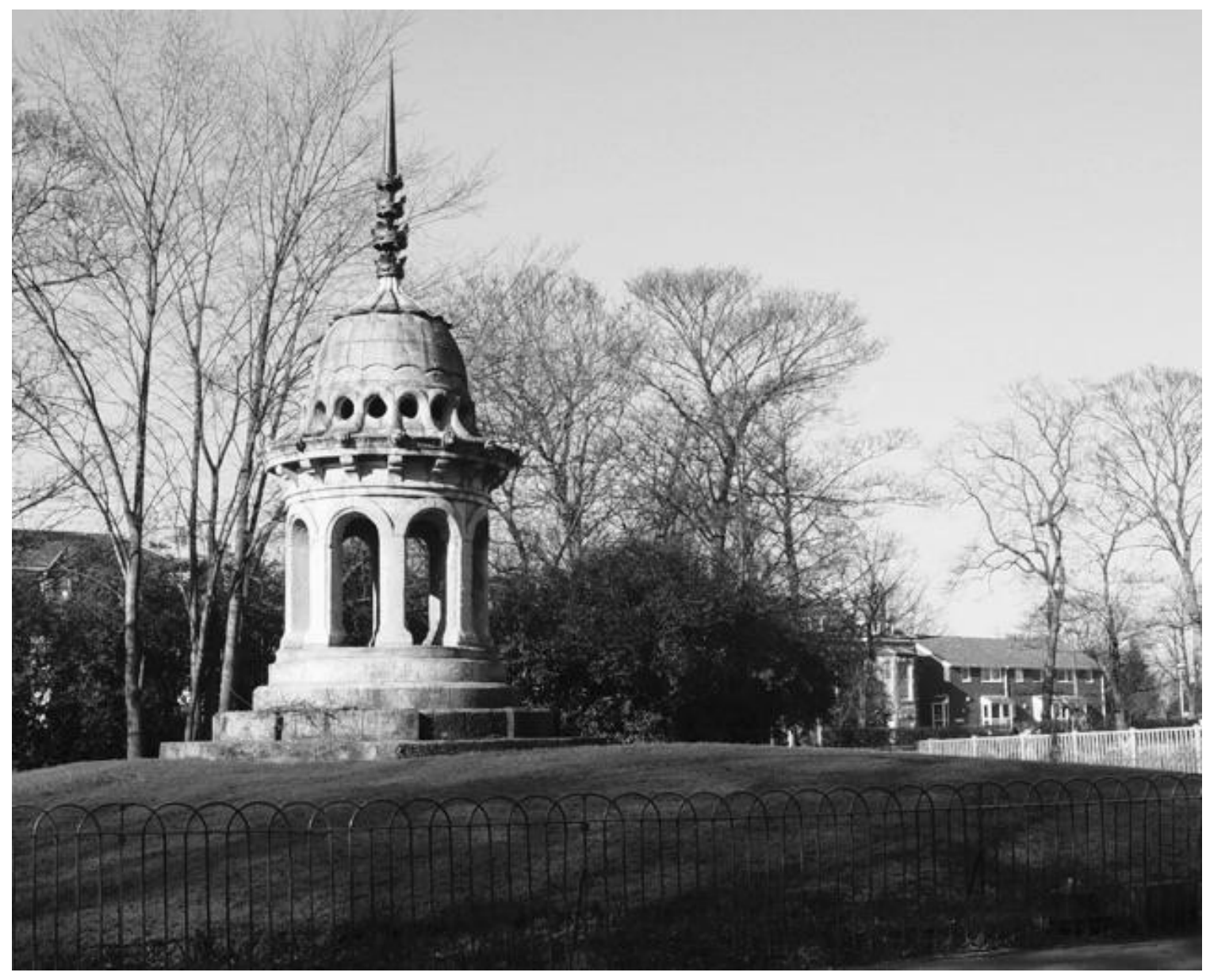

Figure 4 - The dome from the Old Town Hall, Pearson Park, Hull (Photo @ Peter Church (cc-by-sa/2.0) 
Figure captions

Figure 1 - The Old Town Hall, King Street, Manchester with the colonnade in situ (Manchester Central Library, Local Image collection)

Figure 2 - The façade at Heaton Park (Manchester Central Library, Local Image collection)

Figure 3 - The National Monument, Calton Hill, Edinburgh (author photo)

Figure 4 - The dome from the Old Town Hall, Pearson Park, Hull (Photo @ $\underline{\text { Peter }}$ Church (cc-by-sa/2.0) 


\section{PRIMARY SOURCES}

HHC Hull History Centre

MA Manchester Archives

\section{BIBLIOGRAPHY}

Archer, J.H.G., 1963. Edgar Wood: A Notable Manchester Architect. Transactions of the Lancashire and Cheshire Antiquarian Society, 73, 153-187.

Bailey, P., 1978. Leisure and Class in Victorian England: Rational Recreation and the Contest for Control. Toronto: Routledge \& Kegan Paul.

Billinge, M., 1996. A Time and A Place for Everything: An Essay on Recreation, Recreation and the Victorians. Journal of Historical Geography, 22 (4), 443-459.

Briggs, A., 1968. Victorian Cities. London: Penguin Books.

Conway, H., 1991. People's Parks: The Design and Development of Victorian Parks in Britain. Cambridge: University Press.

Cunningham, C., 1981. Victorian and Edwardian Town Halls. London: Routledge and Kegan Paul.

Cunningham, H., 1980. Leisure in the Industrial Revolution. London: Croom Helm.

Fleming, J., et al., eds., 1999. Penguin Dictionary of Architecture and Landscape Architecture. 5th ed. London: Penguin Books.

Glendinning, M., 2003. The Conservation Movement: A Cult of the Modern Age. Transactions of the Royal Historical Society. 13, 359-376. 
Glendinning, M., 2013. The Conservation Movement: A History of Architectural Preservation Antiquity to Modernity. London and New York: Routledge.

Harris, J., 1993. Private Lives, Public Spirit: A Social History of Britain 1870 - 1914. Oxford: University Press.

Harrison, M., 1985. Art and Philanthropy: T.C. Horsfall and the Manchester Art Museum. In: A. J. Kidd and K. W. Roberts, eds. City, Class \& Culture. Manchester: University Press, $120-147$.

Hartwell, C and Wyke, T., 2007. Perspectives. In: C. HARTWELL and T. WYKE (eds). Making Manchester: Aspects of the History of Architecture in the City and Region Since 1800. Manchester: Transactions of the Lancashire and Cheshire Antiquarian Society, 117.

Hobsbawm, E., 1983. Introduction: Inventing Traditions. In: E. Hobsbawm and T. Ranger, eds. The Invention of Tradition. Cambridge: University Press, 1-15.

Horsfall, TC., 1905. The Improvement of the Dwellings and Surroundings of the People. Manchester: Manchester University Press.

Kidd, A., 1997. National Image and Self Image; Manchester since the Industrial Revolution. Manchester: Portico Library.

Konrad, V., 1977. Presenting Our Native Heritage in Public Parks. Recreation Canada, 35 (3), 18-25.

Lowenthal, D., 1985. The Past Is A Foreign Country. Cambridge: University Press.

Manchester City News, 1896. Clayton Hall: its Historical Associations. Manchester City News, 18 April, p. 5. 
Manchester City News, 1912. Manchester Notes. Manchester City News, 4 May, p. 8.

Manchester City News, 1912. Letters. Manchester City News, 18 May, p. 8.

Manchester City News, 1913. City Council Topics: An Unwanted Gift. Manchester City News, 8 June, p. 6.

Manchester City Council Proceedings, 1915. Manchester: Manchester City Council. 20 August 1915, 529.

Manchester Courier, 1912. Concilio et Labore. Manchester Courier, 16 May, p. 6.

Manchester Courier, 1912. Concilio et Labore. Manchester City News, 7 June, p. 6.

Manchester Guardian, 1912. The Old Town Hall Façade. Manchester Guardian, 16

February, p. 8.

Manchester Guardian, 1912. Manchester Council. Manchester Guardian, 6 June, p. 11.

Manchester Evening News, 1912. The Old Town Hall Façade. Manchester Evening News, 17 May, p. 3.

Manchester Guardian, 1913. Letters. Manchester Guardian, 31 October, p. 3.

Marne, P., 2001. Whose public space was it anyway? Class, gender and ethnicity in the creation of the Sefton and Stanley Parks, Liverpool: 1858 - 1872. Social and Cultural Geography, 2 (4), 421-443.

Meacham, S. 1994. Raymond Unwin 1863 - 1940: Designing for Democracy in Edwardian England. In: S. Pedersen and P. Mandler, eds. After the Victorians: Private 
Conscience and Public Duty in Modern Britain. London and New York: Routledge, 79104.

Moore, J., 2006. The Transformation of Urban Liberalism: Party Politics and Urban Governance in Late Nineteenth Century England. Aldershot: Ashgate.

Morgan, S., 1998. Memory and the Merchants: Commemoration and Civic Identity. International Journal of Heritage Studies, 4 (2), 103-113.

Offer, A., 1981. Property and Politics 1870-1914: Landownership, Law, Ideology and Urban Development. Cambridge: University Press.

O'Reilly, C., 2009. Aristocratic Fortunes and Civic Aspiration: Issues in the Passage of Aristocratic Land to Municipal Ownership in Later Nineteenth and Early Twentieth Century Manchester with Particular Reference to the Sale of Heaton Park. Thesis (PhD). Manchester Metropolitan University.

Pevsner, N., 1969. The Buildings of England: South Lancashire. London: Penguin Books.

Schama, S., 1996. Landscape and Memory. London: Fontana Press.

Service, A., 1977. Edwardian Architecture: A Handbook to Building Design in Britain 1890 - 1914. London: Thames and Hudson.

Stedman Jones, G., 1983. Languages of Class: Studies in English Working Class History 1832 - 1982. Cambridge: Cambridge University Press.

Stobart, J., 2003. Identity, Competition and Place Promotion in the Five Towns. Urban History, 30 (2), 164-182. 
Stobart, J., 2004. Building an Urban Identity. Cultural Space and Civic Boosterism in a 'New’ Industrial Town: Burslem, 1761 - 1911. Social History, 29 (4), 485-498.

Summerson, J., 1993. Architecture in Britain $1530-1830.9^{\text {th }}$ ed. New Haven and London: Yale University Press.

Turner, F., 1981. The Greek Heritage in Victorian Britain. London and New Haven: Yale University Press.

Waterson, M., 1994. The National Trust: The First Hundred Years. London: The National Trust.

White, D., 2006. Public Art and Regional Identity: Sheffield: Steel City? A Changing Picture. Conference paper delivered to Regionalism and Identity in British Art: History, Environment and Contemporary Practice, University of the West of England.

Wyke, T., 2006. Marginal Figures? Public Statues and Public Parks in the Manchester Region 1840 - 1914. In: P. Eyres and F. Russell, eds. Sculpture and the Garden. Aldershot: Ashgate, 2006, 85-98.

Wyke, T., 2007. The Albert Memorial and the Making of Civic Manchester. In: C. Hartwell and T. Wyke, eds. Making Manchester: Aspects of the History of Architecture in the City and Region Since 1800. Manchester: Transactions of the Lancashire and Cheshire Antiquarian Society, 90-115. 
